\title{
STUDI KUALITATIF DUKUNGAN KELUARGA DAN MOTIVASI TERHADAP KESEMBUHAN PADA PENDERITA TUBERKULOSIS PARU DI WILAYAH KERJA PUSKESMAS KEMARAYAKOTA KENDARI TAHUN 2019
}

\author{
Farit Rezal ${ }^{1}$ Fifi Nirmala $\mathbf{G}^{2}$ Widya Utari Syafri ${ }^{3}$ \\ 1,2,3 Universitas Halu Oleo Kendari \\ ${ }^{1}$ faritrezz@gmail.com2fifinirmala87@gmail.com ${ }^{3}$ widyautari048@gmail.com ${ }^{3}$
}

\begin{abstract}
Tuberkulosis paru merupakan penyakit menular yang menyerang paru disebabkan oleh mycobacterium tuberculosis. Pengobatan TB paru memerlukan waktu yang cukup lama, sehingga kelangsungan pengobatan TB paru membutuhkan faktor penunjang yaitu salah satunya adalah dukungan keluarga. Penelitian ini bertujuan untuk mengetahui dukungan keluarga dan motivasi terhadap kesembuhan pada penderita tuberkulosis paru di Wilayah Kerja Puskesmas Kemaraya Kota Kendari Tahun 2019. Jenis penelitian yang digunakan adalah penelitian kualitatif dengan pendekatan fenomenologis. Pemilihan informan pada penelitian ini menggunakan teknik purposive sampling, 6 informan kunci dan 2 informan biasa. Hasil penelitian menunjukkan bahwa motivasi kesembuhan yang paling dominan dalam menunjang kesembuhan penderita adalah dukungan keluarga dalam bentuk dukungan emosional yaitu dukungan perhatian terhadap pemenuhan makanan dan yang paling utama adalah perhatian dalam mengontrol pengobatan penderita. Penderita sendiri merasa lebih termotivasi dengan adanya dukungan perhatian yang lebih dari keluarga. Petugas kesehatan memberikan penderita motivasi untuk selalu sabar, ikhlas dan semangat dalam menjalani pengobatan hingga sembuh serta tidak mudah untuk berputus asa. Peranan kader kesehatan dalam melayani pasien TB Paru diharapkan dapat membangun hubungan yang baik dengan penderita.
\end{abstract}

Kata kunci: Tuberkulosis paru, dukungan keluarga, motivasi

\begin{abstract}
Pulmonary tuberculosis is an infectious disease that attacks the lungs caused by Mycobacterium tuberculosis. Treatment of pulmonary TB requires a long time, so the continuity of treatment for pulmonary TB requires supporting factors, one of which is family support. This study aimed to determine family support and healing motivation in pulmonary tuberculosis patients in the Kemaraya Health Center Working Area of Kendari City 2019. The type of study was qualitative study with a phenomenological approach. The selection of informants in this study used a purposive sampling technique, 6 key informants and 2 ordinary informants. The results showed that the most dominant of the recovery of patients was family support in the form of emotional support, namely the support of attention to the fulfillment of food and most importantly, the attention in controlling the treatment of patients. Patients felt more motivated by the support of more attention from the family. Health workers provide patients with motivation to always be patient, sincere and enthusiastic in undergoing treatment until healed and it is not easy to despair. The role of health cadres in serving patients with pulmonary TB was expected to build good relationships with sufferers.
\end{abstract}

Keywords: Pulmonary Tuberculosis, family support, motivation 


\section{PENDAHULUAN}

Berdasarkan laporan World Health Organization (WHO) dalam Global Tuberculosis Report 2017, tingkat penyakit TB di dunia pada tahun 2016, yaitu 10,4 juta orang terindikasi TB, 1,7 juta diantaranya meninggal, dan 0,4 juta pasien meninggal dinyatakan positif HIV. Berdasarkan laporan WHO tersebut, 1 juta anak terkena TB dan 250.000 anak meninggal akibat TB. Indonesia merupakan negara kedua terbanyak penderita TB setelah India, yaitu dengan total penderita 1 juta kasus atau $0,4 \%$ dari seluruh penduduk Indonesia ${ }^{1}$.

Target MDGs untuk pengendalian TB tahun 2015 untuk angka kematian adalah 46/100.000 penduduk, proporsi kasus TB yang terdeteksi $70 \%$ proporsi keberhasilan pengobatan $85 \%$. Pada tahun 2010 angka kematian sudah menurun menjadi 27/100.00 penduduk, proporsi kasus TB sebesar $78,3 \%$ dan proporsi keberhasilan pengobatan $91,2 \%$. Untuk mempercepat pencapaian MDGs pengendalian TB, maka pada tahun 2011 telah diluncurkan Strategi Nasional Pengendalian TB dan Rencana Aksi Nasional Periode 2011-2014 untuk menjadi acuan seluruh Provinsi dan Kabupaten/Kota di Indonesia ${ }^{2}$.

Tuberkulosis merupakan penyakit menular yang menyerang paru yang disebabkan oleh kuman dari kelompok Mycobacterium yaitu Mycobacterium Tuberculosis. TB paru merupakan penyakit dengan tingkat morbiditas tinggi dan sangat mudah menyebar di udara melalui sputum (air ludah) yang dibuang sembarangan di jalan oleh penderita TB paru. Oleh sebab itu TB paru harus ditangani dengan segera dan hati-hati apabila ditemukan kasus tersebut di suatu wilayah. TB paru sampai saat ini masih menjadi satu masalah kesehatan masyarakat di dunia walaupun upaya pengendalian strategi DOTS (Direct Observed Treatment, Shorcouse chemotherapy) telah diterapkan di banyak Negara sejak tahun $1995^{3}$.

Berdasarkan profil kesehatan Kabupaten/Kota, prevalensi TB Paru BTA positif (BTA+) di Provinsi Sulawesi Tenggara tahun 2016 berjumlah 3.105, menurun dibandingkan tahun 2015 dengan jumlah prevalensi sebesar 3.268. Angka kesembuhan (cure rate) pada tahun 2015 mencapai 87,15\%, sedangkan pada tahun 2016 cakupan tersebut sedikit naik menjadi $88,40 \%$, pencapaian kesembuhan di tahun 2016 Sulawesi Tenggara telah mencapai standar target Renstra Kemenkes, tapi masih dibawah standar WHO. Sedangkan angka kesuksesan (success rate) sudah mencapai 91.61\%. Dari 17 Kabupaten/Kota yang terdapat di Sulawesi Tenggara pada tahun 2016, jumlah prevalensi TB paru tertinggi terdapat di Kota Kendari sebanyak 583, prevalensi TB paru di Kabupaten Konawe sebanyak
412, Kabupaten Kolaka sebanyak 215, Kabupaten Konawe Utara sebanyak 85, dan prevalensi TB paru di Kabupaten Buton Utara sebanyak 49. Sedangkan jumlah kasus TB terendah berada di Kabupaten Konawe Kepulauan sebanyak 23 kasus $^{4}$.

Dari data sekunder yang diperoleh dari Dinas Kota Kendari, pada tahun 2016 ditemukan jumlah suspek sebanyak 7632 dengan penemuan prevalensi BTA+ sebanyak 583, meningkat bila dibandingan angka prevalensi BTA+ yang ditemukan pada tahun 2015 yang sebesar 545 . Jumlah prevalensi TB paru tertinggi yang dilaporkan terdapat di Puskesmas Kemaraya dan Puskesmas Puuwatu. Kasus barus BTA+ di tiga Puskesmas tersebut sebesar 50\% dari jumlah kasus baru di Kota Kendari ${ }^{5}$.

Dari data sekunder yang diperoleh dari Dinas Kota Kendari, pada tahun 2017 ditemukan jumlah prevalensi tuberkulosis sebanyak 545 , menurun bila dibandingkan dengan prevalensi tuberkulosis yang ditemukan pada tahun 2016 yang sebesar 583. Jumlah prevalensi tertinggi yang dilaporkan terdapat di Puskesmas Kemaraya, Puskesmas Puuwatu dan Puskesmas Benu-Benua. Prevalensi BTA+ di dua Puskesmas tersebut sebesar $60 \%$ dari jumlah insidensi di Kota Kendari. Pada tahun 2017 angka keberhasilan pengobatan semua kasus tuberkulosis sebesar $100 \%$ Angka kesembuhan semua kasus yang harus dicapai minimal $85 \%$, berarti dalam hal ini kasus tuberkulosis mencapai target SPM $2016^{5}$.

TB Paru adalah penyakit yang dapat diobati dan disembuhkan. Pengobatan TB Paru dapat diberikan dalam 2 tahap, yaitu tahap intensif 2 bulan pengobatan dan tahap lanjutan 4-6 bulan berikutnya. Pengobatan yang teratur pada pasien TB Paru dapat sembuh secara total, apabila pasien itu sendiri mau patuh dengan aturan-aturan tentang pengobatan TB Paru. Sangatlah penting bagi penderita untuk tidak putus berobat dan jika penderita menghentikan pengobatan, kuman TB Paru akan mulai berkembang biak lagi yang berarti penderita mengulangi pengobatan intensif selama 2 bulan pertama ${ }^{6}$.

Program pengobatan pada penderita TB paru selain untuk mengobati juga mencegah kematian, mencegah kekambuhan atau resistensi terhadap OAT (Obat Anti Tuberkulosis) serta memutuskan mata rantai penularan. Pengobatan TB paru memerlukan waktu cukup lama, yakni enam bulan sampai delapan bulan secara terus menerus (teratur) dengan OAT (Obat Anti Tuberkulosis) dan harus dilakukan dengan tuntas sampai sembuh sehingga dapat mencegah penularan pada orang $\operatorname{lain}^{7}$. Faktor penunjang kelangsungan pengobatan adalah pengetahuan penderita mengenai bahaya penyakit TB paru yang mudah menular, motivasi keluarga baik saran dan perilaku keluarga kepada 
penderita untuk menyelesaikan pengobatannya dan penjelasan atau pendidikan kesehatan dari petugas kesehatan tentang pentingnya kepatuhan pengobatan dan dukungan keluarga dalam kepatuhan pengobatan penderita TB paru.

Dukungan sosial yang utama berasal dari dukungan keluarga, karena dukungan keluarga memengang peranan penting dalam kehidupan penderita tuberkulosis berjuang untuk sembuh, berpikir kedepan, dan menjadikan hidupnya lebih bermakna ${ }^{8}$. Akibat kurang mendapatkan dukungan sosial dari keluarga dan lingkungan sekitar menimbulkan gangguan psikologis pada penderita tuberkulosis meliputi: depresi, gangguan penyesuaian, ansietas, hilangnya tujuan hidup, melemahnya produktifitas, fobia dan lainnya ${ }^{9}$. Penelitian terdahulu menemukan bahwa ada hubungan yang bermakna antara dukungan keluarga terhadap kepatuhan minum obat anti tuberkulosis. Hasil analisis menunjukkan bahwa dukungan keluarga yang baik, akan meningkatkan kepatuhan klien minum obat anti tuberkulosis ${ }^{10}$. Penelitian lain menjelaskan bahwa ada efek langsung dukungan sosial terhadap motivasi klien TB untuk sembuh dari penyakitnya $^{11}$. Seseorang akan sembuh lebih cepat dari sakit bila keluarganya membantunya memecahkan masalah kesehatan yang kronis juga didukung oleh adanya sistem yang efektif dari dukungan sosial ${ }^{12}$.

Berdasarkan latar belakang diatas, peneliti tertarik untuk melakukan penelitian dengan judul "Studi Kualitatif Dukungan Keluarga Dan Motivasi Terhadap Kesembuhan Pada Penderita Tuberkulosis Di Wilayah Kerja Puskesmas Kemaraya Kota Kendari Tahun 2019". Prevalensi tuberkulosis paru di Puskesmas Kemaraya pada tahun 2016 sebanyak 80 orang penderita. Sedangkan pada tahun 2017 prevalensi TB Paru sebanyak 104 penderita.

\section{METODE}

Jenis penelitian ini adalah penelitian kualitatif. Penelitian kualitatif merupakan proses penelitian yang bertujuan memahami suatu masalah kemanusiaan yang didasarkan pada penyusunan suatu gambaran yang kompleks dan menyeluruh menurut pandangan yang rinci dari para informan serta dilaksanakan di tengah setting alamiah.

\section{HASIL DAN DISKUSI}

Informan dalam penelitian ini terdiri dari 6 informan kunci dan 2 informan biasa. Adapun informan kunci adalah penderita tuberkulosis paru yang telah sembuh dan terlibat langsung dalam interaksi sosial yang diteliti. Adapun informan biasa adalah petugas kesehatan yang bertugas di
Puskesmas Kemaraya Kota Kendari.

Tabel 1. Distribusi Informan Penelitian

\begin{tabular}{cccccc}
\hline No & Inisial & $\begin{array}{c}\text { Umur } \\
\text { (Thn) }\end{array}$ & Jenis Kelamin & Pekerjaan & $\begin{array}{c}\text { Jenis } \\
\text { Informan }\end{array}$ \\
\hline 1 & HA & 22 & Laki-Laki & Mahasiswa & Kunci \\
2 & AD & 74 & Laki-Laki & Pensiunan & Kunci \\
3 & LB & 65 & Laki-Laki & Wiraswasta & Kunci \\
4 & HW & 34 & Perempuan & IRT & Kunci \\
5 & A & 21 & Laki-Laki & Mahasiswa & Kunci \\
6 & AS & 42 & Perempuan & IRT & Kunci \\
7 & H & 41 & Laki-Laki & PNS & Biasa \\
8 & NP & 34 & Perempuan & PNS & Biasa \\
\hline
\end{tabular}

Dukungan keluarga pada umumnya akan menggambarkan mengenai peran atau pengaruh serta bantuan yang diberikan oleh orang yang berarti seperti anggota keluarga, teman, saudara, dan rekan kerja. Individu yang memiliki dukungan keluarga yang lebih kecil, lebih memungkinkan akan mengalami kesulitan dalam menyelesaikan masalah, mengambil keputusan, dan penilaian negatif terhadap masalah, sehingga merasa terbebani. Keuntungan individu yang memperoleh dukungan keluarga yang tinggi akan menjadi individu lebih optimis dalam menghadapi kehidupan saat ini maupun masa yang akan datang ${ }^{13}$.

Dukungan Emosional

Dukungan emosional keluarga merupakan bagian dari dukungan yang dapat memberikan kenyamanan, bantuan, kepedulian, maupun penghargaan bagi individu atau kelompok. bentuk dukungan emosional yang dapat diberikan adalah ungkapan empati, kepedulian dan ungkapan perhatian dari orang lain $^{14}$. Pada penelitian ini dukungan emosional yang dimaksud bagaimana keluarga dalam mengekspresikan sesuatu, baik itu perhatian maupun semangat karena dengan adanya kepedulian antar sesama anggota keluarga akan memberikan kesembuhan lebih meningkat lagi bagi anggota keluarga yang sedang sakit.

Berdasarkan hasil wawancara mendalam dengan informan kunci maupun informan biasa, diperoleh bahwa dukungan emosional keluarga kepada penderita tuberkulosis paru (TB) dapat dikatakan baik. Dimana dari hasil penelitian yang diperoleh, dukungan emosional yang diberikan keluarga pada penderita yaitu keluarga mengawasi aktivitas penderita agar penderita beristirahat yang cukup dan tidak melakukan kegiatan berlebihan. Keluarga juga memberikandukungan perhatian, semangat, serta motivasi yang tinggi dalam menjalani masa pengobatan. Keluarga juga memberikan perhatian dalam bentuk ekspresi dengan melarang penderita untuk melakukan pekerjaan yang berat dan selalu menekankan pada penderita untuk lebih banyak istirahat.

Dengan adanya rasa sayang yang diberikan oleh keluarga pada penderita tuberkulosis paru 
dapat mengurangi rasa cemas, keputusasaan, serta rasa kepercayaan diri pada penderita akan lebih meningkat. Hal ini diperkuat oleh teori yang mengatakan bahwa dukungan emosional merupakan wujud kasih sayang yang diberikan oleh keluarga kepada salah satu anggota keluarga yang menderita suatu penyakit ${ }^{15}$. Dukungan emosional yang diberikan keluarga ini sangat mempengaruhi penyembuhan pasien. Dukungan emosional yang diberikan keluarga kepada pasien akan mendorong pasien untuk menjalani pengobatan secara teratur, hal ini dikarenakan dukungan yang diberikan tersebut dijadikan sebagai energi penggerak bagi pasien dalam menjalankan suatu program terapi ${ }^{16}$.

Selain itu, keluarga juga memberikan rasa empati pada penderita tuberkulosis paru dengan cara membantu menemani dalam mengambilkan obat untuk pasien. Empati sendiri bertujuan untuk memecahkan masalah yang dinilai cukup berat oleh penderita. Bagi penderita, empati dari keluarga akan membuat penderita merasa aman dan merasa diperhatikan. Penderita tuberkulosis paru harus menjalani pengobatan yang lama yaitu selama 6 bulan tanpa berhenti, hal ini akan menimbulkan kejenuhan tersendiri bagi penderita. Oleh karena itu, dukungan emosi dari keluarga sangat dibutuhkan oleh penderita untuk mengurangi kejenuhan yang dirasakan oleh penderita selama pengobatan berlangsung, baik itu dalam bentuk perhatian, empati maupun kepedulian terhadap penderita yang mampu mengurangi kejenuhan penderita.

Hal ini sejalan dengan hasil penelitian sebelumnya terhadap dukungan sosial pada pasien TB di Bogor. Dimana hasil penelitian tersebut menunjukkan bahwa lebih dari tiga perempat contoh penderita TB Paru (78\%) mendapatkan dukungan emosional yang sedang ${ }^{17}$.

Dukungan emosional yang baik yang dirasakan oleh seseorang ketika ia menghadapi sumber stress dalam hidupnya akan membantu individu tersebut beradaptasi dan memiliki mekanisme koping yang adaptif yang membantunya mengatasi masalah ${ }^{16}$. Dukungan emosional yang diberikan keluarga pada penderita akan mendorong penderita untuk mau menjalani pengobatan secara teratur, dimana penderita menjadikan dukungan emosional yang diberikan keluarga tersebut sebagai salah satu penggerak dalam dirinya untuk menjalani pengobatannya.

Dari informan kunci penderita pada penelitin ini terdapat satu informan kunci yaitu penderita yang sudah sembuh ternyata tidak mendapatkan dukungan emosional dari keluarganya selama sakit. Informan kunci HA menjalani masa pengobatan tanpa mendapatkandukungan emosional dari keluarga, baik itu dari segi perhatian dan kasih sayang maupun peringatan dan pengawasan dalam menjalai pengobatan dari anggota keluarganya. Informan kunci HA mendapatkan dukungan emosional hanya dari orang-orang yang berada disekitar tempat tinggal HA yang mengetahui dirinya menderita penyakit tuberkulosis paru. Dalam segi pengobatan, penderita HA selalu memperhatikan jadwal makan dan minum obatnya sehingga tanpa pengawasan ataupun peringatan dari keluarga, penderita tetap rutin dalam menjalani pengobatannya.

Sedangkan dari hasil observasi yang dilakukan peneliti pun menunjukkan bahwa penderista memperoleh dukungan emosional dari keluarga dimana keluarga berada didekat pasien, tidak ada perbedaan perlakuan dari keluarga terhadap penderita, serta penderita juga tidak menyendiri melainkan selalu berada didekat anggota keluarganya.

\section{Dukungan Instrumental}

Dukungan instrumental merupakan dukungan yang diberikan kepada penderita dalam bentuk dana, pengawasan ketat, pemberian pertolongan dan lain-lain ${ }^{15}$. Keluarga merupakan sebuah sumber pertolongan praktis dan konkrit, diantaranya kesehatan penderita dalam hal kebutuhan makan dan minum, istirahat, terhindarnya penderita dari kelelahan, dan kebutuhan minum obat penderita.

Berdasarkan hasil wawancara mendalam dengan informan kunci dan informan biasa, diperoleh bahwa dukungan instrumental yang diberikan keluarga adalah pemenuhan makanan yang bernutrisi seperti sayuran dan buah-buahan. Keluarga juga mengingatkan penderita untuk tidak mengkonsumsi makanan yang menjadi pantangan dari penyakit tuberkulosis paru yang sedang diderita.

Pada usia berapapun tubuh hanya dapat melawan infeksi apabila dicukupi oleh makanan yang bergizi dalam jumlah cukup ${ }^{18}$. Malnutrisi dan berkurangnya daya tahan tubuh dapat meningkatkan keparahan penyakit dan meningkatkan kematian. Penurunan daya tahan tubuh dapat dipengaruhi oleh terinfeksi Human Immunodeficiency Virus/Acquired Immunodeficiency Virus (HIV/AIDS) dan malnutrisi apabila kekurangan kalori, protein, dan zat gizi (gizi buruk) yang dapat meningkatkan risiko terinfeksi TB paru ${ }^{19}$. Status gizi buruk pada pasien akan menyebabkan kekebalan tubuh yang menurun sehingga memudahkan terinfeksi TB paru. Peningkatan dan perbaikan status gizi dengan memberikan asupan makanan yang seimbang pada pasien TB paru yang sedang menjalani pengobatan merupakan faktor penentu keberhasilan konversi dahak BTA pasien TB Paru ${ }^{20}$. 
Dukungan instrumental lain yang diberikan keluarga adalah membantu atau meringankan pekerjaan penderita dalam aktivitas sehari-hari seperti mencuci pakaian dan seprai tempat tidur penderita. Dengan membantu meringankan aktivitas penderita seperti mencucikan pakaiana dan seprai tempat tidurnya, maka penderita akan lebih banyak memiliki waktu untuk istirahat. Keluarga juga membantu menyiapkan barang keperluan yang butuhkan oleh penderita seperti menyediakan pakaian yang akan digunakan oleh penderita dan masker. Masker sendiri sangat dibutuhkan oleh penderita tuberkulosis paru untuk membatasi kontak langsung dengan orang lain yang berada disekitarnya, hal tersebut guna menghindari penularan penyakit yang dapat terjadi. Penggunaan masker juga untuk menghindari paparan debu serta asap rokok yang bisa memperburuk penderita.

Selain itu, keluarga juga selalu menjaga kebersihan dari penderita dengan selalu mengepel lantai kamar penderita. Dari informan kunci keluarga penderita, salah satu informan keluarga melakukan alternatif dengan membuat tempat meludah bagi penderita untuk menghindari penderita meludah di sembarang tempat. Keluarga juga selalu menyiapkan masker yang akan digunakan penderita baik didalam rumah maupun diluar rumah. Keluarga selalu berusaha untuk mencegah terjadinya penularan penyakit yang sedang diderita anggota keluarganya agar tidak menambah penderita baru dianggota keluarga.

Penelitian ini sejalan dengan hasil penelitian sebelumnya tentang Dukungan Sosial Penderita Tuberkulosis Paru Di Kabupaten Bone. Hasil penelitian menunjukkan bahwa penderita memperoleh dukungan instrumental dari keluarganya dalam hal pemenuhan kebutuhan sehari-hari seperti penyediaan makanan, mencuci serta memandikan penderita ${ }^{21}$.

Dukungan instrumental lain yang diperoleh pada penelitian ini adalah keluarga membantu dalam pembiayaan penderita, dimana keluarga tidak begitu terbebani oleh pembiayaan pengobatan penderita karena untuk pengobatan tuberkulosis paru sendiri tidak dipungut biaya dengan kata lain gratis. Akan tetapi jika memang ada keperluan lain yang membutuhkan biaya, keluarga penderita tetap membantu dalam proses pembiayaan penderita. Keluarga juga dipermudah dengan menggunakan program pemerintah yaitu BPJS, pihak puskesmas pun mengarahkan keluarga melakukan registrasi untuk mengurus BPJS mandiri bila ada biaya layanan dasar yang bersifat umum. Selain menggunakan BPJS, salah satu informan kunci penderita menggunakan kartu bahteramas. Kartu bahteramas ini digunakan penderita untuk pengobatan baik di puskesmas maupun di rumah sakit tanpa dipungut biaya.

Dari semua informan kunci penderita tuberkulosis paru dalam penelitian ini, terdapat satu informan kunci yaitu HA yang tidak pula mendapat dukungan instrumental dari keluarganya. Dukungan instrumental dalam bentuk pemberian makanan dan pemenuhan nutrisi pun dipenuhi sendiri oleh penderita, dimana untuk makanan yang dikonsumsi penderita selama sakit yaitu makanan yang menurut penderita baik untuk dikonsumsi selama sakit. Penderita mendapat dukungan instrumental dari teman maupun tetangga yang berada disekitar lokasi tempat tinggal penderita dalam bentuk selalu mengingatkan penderita untuk rutin mengkonsumsi obat. Sedangkan untuk pembiayaan pengobatan yang membutuhkan biaya, penderita mendapat bantuan dari ibu kosnya.

Sedangkan dari hasil observasi yang dilakukan peneliti pun menunjukkan bahwa penderita memperoleh dukungan instrumental dari keluarga mengingatkan penderita untuk minum obat, menyiapkan makanan penderita serta selalu menjaga kebersihan diri penderita.

\section{Dukungan Informasi}

Dukungan informasi yang dilakukan keluarga dalam meningkatkan kesehatan anggota keluarga dapat berupa memberikan saran, nasehat, sumber informasi, serta melibatkan orang yang dihormati dalam proses penyampaian informasi yang didapatkan kepada anggota keluarga yang membutuhkan ${ }^{22}$.

Berdasarkan hasil wawancara mendalam dengan informan kunci dan informan biasa, diperoleh bahwa dukungan informasi yang diberikan keluarga pada penderita tuberkulosis paru yaitu pemberitahuan tentang peringatan risiko yang akan terjadi jika penderita tidak meminum obat secara rutin. Hal ini didukung oleh informasi yang selalu disampaikan oleh pihak petugas kesehatan untuk selalu memperhatikan jadwal minum obat penderita, karena jika penderita tidak mengkonsumsi obat secara teratur maka penderita akan mengulangi pengobatannya kembali dari awal. Pengobatan tuberkulosis paru sendiri dijalani dalam jangka waktu 6 bulan dengan mengkonsumsi obat yang memiliki dosis yang sangat tinggi sehingga akan menimbulkan beberapa efek samping. Pihak puskesmas juga menginformasikan pada keluarga jika penderita putus berobat walau hanya sehari saja, maka kuman yang ada di dalam tubuh mengalami resisten sehinga harus dilakukan penyuntikkan sebanyak 4 kali sehari serta akan dilakukan isolasi terhadap penderita.

Dukungan informasi yang diberikan keluarga pada penderita tuberkulosis paru adalah dengan 
selalu memberikan saran-saran maupun nasehat pada penderita terkait kesembuhannya seperti selalu mengingatkan penderita untuk banyak beristirahat serta tidak melakukan aktivitas berat yang dapat menguras tenaga penderita. Selain itu, keluarga juga selalu mengingatkan penderita untuk minum obat secara teratur serta selalu menggunakan masker untuk menghindari terjadinya penularan.

Selain itu, dukungan informasi lain yang diberikan oleh keluarga terhadap penderita tuberkulosis paru adalah dengan mencari informasi tambahan terkait penyakit yang sedang diderita anggota keluarganya yaitu terkait penyakit TB itu sendiri, baik itu dari segi pencegahan, pengobatan maupun penanggulan tuberkulosis. Informasi yang diperoleh keluarga dari berbagai pihak yaitu dokter, petugas kesehatan puskesmas, tetangga yang pernah mengalami penyakit tuberkulosis. Keluarga selalu berusaha mencari informasi tambahan dari berbagai sumber terkait penyakit yang sedang diderita anggota keluarganya dengan tujuan dapat terbantu dalam merawat anggota keluarga yang sedang menderita penyakit tuberkulosis paru dengan benar.

Penelitian ini sejalan dengan penelitian sebelumnya tentang Gambaran Dukungan Sosial Keluarga Terhadap Klien Tuberkulosis Paru Puskesmas Kecamatan Jagakarsa. Dimana hasil penelitian menunjukkan bahwa dukungan informasi yang diperoleh klien TB yang berobat di Puskesmas Kecamatan Jagakarsa cukup tinggi (97\%) sehingga klien TB memiliki potensi yang tinggi untuk patuh minum obat dan sembuh dari penyakitnya, terutama jika didukung dengan informasi yang benar tentang penyakitnya dari petugas kesehatan ${ }^{12}$.

Dukungan informasi lain yang diberikan keluarga adalah pemberian masukan dan saran dalam mendukung kesembuhan penderita. Dimana keluarga memberikan masukan maupun saran pada penderita dalam bentuk menyarankan penderita untuk selalu istirahat yang cukup.

Sedangkan untuk informan kunci HA pada penelitian ini mendapat dukungan informasi dari orang-orang terdekatnya, baik itu dari teman kuliah, teman kerja, maupun tetangga yang berada disekitar tempat tinggalnya. Penderita mencari informasi terkait penyakit yang diderita dalam bentuk informasi terkait bagaimana perawatan penyakit tuberkulosis, apa saja yang harus dikonsumsi. Penderita juga mencari informasi terkait obat tradisional yang bisa dikonsumsi untuk mendukung kesembuhan dari penyakitnya. Meskipun penderita tidak mendapat dukungan informasi dari keluarga, tetapi penderita tidak tinggal diam melainkan menderita selalu berusaha mencari sendiri informasi tambahan dari berbagai sumber. Dukungan informasi lain yang diterima penderita dari orang terdekatnya yaitu pimpinan ditempat penderita bekerja berupa saran untuk tidak melakukan pekerjaan yang berat.

Dari hasil observasi yang dilakukan peneliti pun menunjukkan bahwa penderita memperoleh dukungan informasi dari keluarga selalu mengingatkan penderita untuk selalu menggunakan masker agar tidak menularkan penyakitnya pada anggota keluarga lainnya.

\section{Dukungan Penghargaan}

Dukungan penghargaan merupakan dukungan dimana keluarga bertindak sebagai pemberi pengakuan dan perhatian kepada anggota keluarga untuk bimbingan umpan balik,membimbing, dorongan maju, atau persetujuan dengan gagasan atau perasaan individu kepada hal yang positif.

Berdasarkan hasil wawancara mendalam dengan informan kunci dan informan biasa, diperoleh bahwa dukungan penghargaan yang diberikan keluarga pada penderita tuberkulosis paru yaitu dengan memberikan perlakuan positif pada penderita, pemberian perhatian yang lebih kepada penderita, selalu mendengarkan keluh kesah dari penderita serta mengajak penderita untuk ikut berdiskusi maupun berkumpul bersama dengan anggota keluarga lain dengan tetap menggunakan alat pelindung diri (APD) yang berlaku yaitu masker. Hal ini dilakukan agar penderita merasa tetap dihargai dan dianggap sebagai anggota keluarga lainnya meskipun dalam keadaan sakit. Hal ini juga akan berdampak pada psikologi penderita, dimana dari segi psikologis penderita tidak ikut sakit.

Selain itu, bentuk dukungan penghargaan lain yang diberikan keluarga terhadap penderita tuberkulosis paru adalah dengan memberikan kritik yang bersifat membangun sehingga penderita dapat termotivasi untuk lebih meningkatkan kesehatannya. Tindakan seseorang mendapatkan pujian atau dorongan positif dari orang lain, maka orang tersebut cenderung akan mengulangi tindakan yang sama ${ }^{23}$.

Penelitian ini sesuai dengan teori yang menyatakan bahwa dukungan penghargaan merupakan dukungan positif yang dapat diberikan kepada individu yang memiliki masalah, bentuk dukungan penghargaan ini dapat berupa ekspresi penghargaan positif dalam bentuk persetujuan terhadap ide-ide atau perasaan seseorang ${ }^{24}$.

Hal ini serupa juga dengan teori yang mengatakan perhatian dan kasih sayang, penderita akan lebih memahami adanya dukungan dari keluarga sehingga akan membantu penderita termotivasi menghadapi penyakit dan berusaha yang terbaik untu sembuh ${ }^{25}$. 
Dukungan penghargaan lain yang diberikan keluarga pada penderita tuberkulosis paru yaitu dengan melibatkan penderita dalam diskusi maupun musyawarah keluarga, keluarga selalu berusaha membuat penderita tidak merasa sendiri dengan selalu menanyakan kondisi terkini dari penderita.

Sedangkan untuk informan kunci HA mendapat dukungan penghargaan hanya dari rekan kuliah, rekan kerja dan tetangga disekitar tempat tinggalnya berupa tidak menjauhi penderita ataupun mengucilkan penderita. Dukungan penghargaan lain yang diperoleh informan kunci HA dari orang-orang terdekatnya yaitu dari rekan-rekan kuliah maupun tempat bekerja, informan selalu diikut seertakan dalam diskusi baik itu diskusi formal maupun informal. Dari hasil observasi yang dilakukan peneliti pun menunjukkan bahwa penderita memperoleh dukungan penghargaan dari keluarga yaitu penderita tetap berkomunikasi dengan keluarga.

\section{Motivasi Kesembuhan}

Motivasi merupakan keinginan yang terdapat pada diri seorang individu yang mendorongnya melakukan tindakan untuk mencapai suatu tujuan ${ }^{26}$. Motivasi tersebut dapat timbul dari dalam diri sendiri, maupun pengaruh dari luar diri individu karena adanya ajakan, suruhan atau paksaan dari orang lain. Oleh karena itu, motivasi yang diperoleh dari dalam diri sendiri maupun dari luar dapat membentuk individu tersebut untuk berperilaku sehat dan menuntutnya untuk sembuh dari penyakit yang dideritanya.

Berdasarkan hasil wawancara mendalam dengan informan kunci dan informan biasa, diperoleh bahwa motivasi yang diberikan keluarga pada penderita tuberkulosis paru yaitu keluarga selalu memberikan motivasi serta semangat kepada penderita dalam menjalani masa pengobatan, serta selalu menguatkan penderita untuk selalu sabar dan tetap berjuang untuk sembuh. Keluarga selalu memberikan motivasi pada penderita agar penderita tetap kuat dan sabar dalam melewati penyakit yang sedang diderita, keluarga selalu memotivais penderita untuk melawan penyakitnya, ikhlas menjalani pengobatan, keluarga selalu memberi semangat juang sembuh pada penderita.

Selain motivasi dari keluarga, penderita juga selalu berusaha memotivasi dirinya sendiri. Salah satu informan kunci yaitu AD dalam penelitian ini selalu menanamkan dalam diri untuk berjuang melawan penyakitnya, penderita ini juga memiliki keinginan untuk sembuh yang besar dalam dirinya sehingga penderita tetap sabar dalam menjalani pengobatan hingga sembuh.

Motivasi dari keluarga sangat dibutuhkan oleh penderita tuberkulosis paru ini untuk berhasil dan teratur dalam pengobatannya hingga sembuh, dikarenakan keluarga selalu mempunyai waktu lebih lama dengan penderita. Keluarga menjadi orang yang paling berpengaruh dalammendukung maupun memberikan motivasi untuk menunjang kesembuhan dari penderita.

Motivasi sendiri merupakan dorongan dalam diri seseorang yang menyebabkan orang tersebut melakukan kegiatan tertentu guna mencapai tujuan tertentu. Motivasi yang ada dalam pasien bertujuan agar mereka dapat sembuh dari sakit TB yang dideritanya.

Penelitian ini sejalan dengan penelitian sebelumnya tentang Pengaruh Sosial Budaya dan Sikap Petugas terhadap Keberhasilan Kesembuhan TB Paru di Puskesmas Semula Jadi Kecamatan Datuk Bandar Timur Kota Tanjungbalai dari hasil analisis multivariat dengan menggunakan uji regresi logistik berganda, variabel motivasi didapatkan nilai $p=$ $0,004(p<0,05)$ dengan nilai $B=19,226$. Dengan demikian dapat disimpulkan bahwa ada pengaruh yang signifikan antara motivasi terhadap keberhasilan kesembuhan TB paru di Puskesmas Semula Jadi Kecamatan Datuk Bandar Timur Kota Tanjungbalai ${ }^{26}$.

Peran motivasi yang ada pada diri responden dalam melaksanakan kesembuhan dapat dijelaskan melalui pendapat yang menyatakan pengertian motivasi adalah yang didorong oleh kekuatan dari dalam. Didasarkan oleh misi atau tujuan hidupnya. Seseorang yang telah menentukan misi hidupnya bekerja berdasarakan nilai yang diyakininya. Dengan demikian juga keberadaan pasien, apabila memiliki motivasi yang baik akan dapat mencapai target cakupan yang ditetapkan dalam program keberhasilan kesembuhan TB paru ${ }^{27}$.

Tidak hanya itu, motivasi kesembuhan yang paling dominan dalam menunjang kesembuhan penderita adalah dukungan keluarga dalam bentuk dukungan emosional yaitu dukungan perhatian lebih terhadap pemenuhan makan penderita serta paling utama adalah perhatian dalam mengontrol pengobatan penderita. Penderita merasa lebih termotivasi dengan adanya dukungan perhatian yang lebih dari keluarga.

Motivasi yang diperoleh penderita pun tidak hanya dari keluarga maupun orang terdekat, tetapi datang dari petugas kesehatan yang juga memberikan motivasi pada penderita untuk sembuh dari penyakitnya. Petugas kesehatan memberikan motivasi untuk selalu sabar, ikhlas dan semangat dalam menjalani pengobatan hingga sembuh serta tidak mudah untuk putus asa. Peranan kader kesehatan dalam melayani pasien TB Paru diharapkan dapat membangun hubungan yang baik dengan pasien. Motivasi dari petugas kesehatan juga diperlukan untuk menunjang penderita teratur 
dalam kontrol berobat ke puskesmas sehingga berhasil dalam pengobatannya.

Dukungan dari petugas kesehatan memberikan pengaruh terhadap kepatuhan pasien. Pasien yang telah mendapatkan dukungan motivasi dari petugas kesehatan untuk selalu tepat waktu mengambil obat ke puskesmas dan memperhatikan perkembangan kesehatan pasien TB, maka pasien TB tersebut akan merasa diperhatikan oleh petugas dan menerima semua anjuran petugas selama pengobatan ${ }^{28}$.

Dari hasil wawancara mendalam yang dilakukan, peneliti juga menanyakan terkait suka duka yang dilalui penderita yang sudah sembuh serta penderita yang sedang menjalankan pengobatan selama 6 bulan. Dimana beberapa informan kunci merasakan suka selama sakit yaitu selalu makan dan tidur. Berbeda dari informan lain yang merasa tidak ada suka selama sakit. Sedangkan untuk duka yang dirasakan ataupun alami semua informan adalah reaksi dari efek yang ditimbulkan setelah mengkonsumsi obat.

Informan kunci lain dalam penelitian ini yaitu HA yang tidak mendapat dukungan dari keluarganya pun memiliki motivasi yang tinggi untuk sembuh dari penyakitnya meskipun tidak ada dukungan yang baik dari keluarganya. Informan ini hanya mengandalkan motivasi yang ditanamkan dalam dirinya serta dukungan-dukungan yang diperoleh dari orangorang terdekat seperti rekan ditempat kuliah, tempat kerja serta tetangganya. Dengan bergantung pada motivasi yang kuat dalam diri untuk sembuh, membuktikan bahwa penderita HA ini berhasil sembuh tanpa adanya dukungan yang baik dari kelurganya.

Sedangkan dari hasil observasi yang dilakukan peneliti menunjukkan bahwa penderita mendapatkan motivasi yang baik dari keluarga dimana penderita menampakkan ekspresi tersenyum serta banyak bicara hal tersebut menujukkan bahwa penderita mendapatkan motivasi dari keluarga sehingga membuat penderita tetap percaya diri.

Dari lima variabel diatas terkait dukungan sosial dan motivasi terhadap kesembuhan pada penderita tuberkulosis paru, maka dibutuhkan adanya aspek promotif dan preventif terkait penyakit tubekulosis paru. Dimana Edukasi dan promosi kesehatan penyakit tuberkulosis paru (TB paru) dilakukan kepada pasien, masyarakat dan keluarganya untuk mencegah penularan dan perkembangan penyakit.

\section{Upaya Pengendalian dan Penanggulangan TB}

Rencana global penanggulangan TB didukung oleh 6 komponen oleh World Health Organization (WHO), yaitu:
1. Mengejar peningkatan dan perluasan DOTS yang berkualitas tinggi

2. Menangani kasus ko-infeksi TB-HIV, kekebalan ganda terhadap obat anti TB

3. Berkontribusi dalam penguatan sistem kesehatan

4. Menyamakan persepsi semua penyedia pelayanan

5. Memberdayakan pasien TB dan masyarakat

6. Mewujudkan dan mempromosikan penelitian

Strategi nasional pengendalian TB telah berjalan dengan petunjuk internasional WHO DOTS dan strategi Stop TB sebelumnya. Kemudian program ini berlanjut dengan rencana global penanggulangan "End TB Strategy" di tahun 2020. Mengakhiri epidemik TB sebelum tahun 2030 adalah salah satu target kesehatan dari Sustainable Development Goals.

Strategi DOTS terdiri dari 5 komponen yaitu komitmen pemerintah untuk mempertahankan kontrol terhadap TB; deteksi kasus TB di antara orang-orang yang memiliki gejala-gejala melalui pemeriksaan dahak; pengobatan teratur selama 6-8 bulan yang diawasi; persediaan obat TB yang rutin dan tidak terputus; dan sistem laporan untuk monitoring dan evaluasi perkembangan pengobatan dan program. Strategi penanggulangan TB terus diperluas, termasuk pengelolaan kasus kekebalan obat anti TB, TB terkait HIV, penguatan sistem kesehatan, keterlibatan seluruh penyedia layanan kesehatan dan masyarakat, serta promosi penelitian.

1. Upaya pencegahan dini

Imunisasi BCG (Bacille Calmatte Guerin) dianjurkan diberikan pada bayi usia $>2$ bulan, sekitar 2-3 bulan. Booster tidak dianjurkan.

2. Upaya Edukasi dan Promosi Kesehatan pada Pasien dan Keluarganya

Program nasional yang berkolaborasi dengan donor organisasi internasional dalam upaya pengendalian tuberkulosis paru juga memasukkan aspek edukasi dan promosi kesehatan kepada pasien, keluarganya dan masyarakat. Profilaksis tuberkulosis, edukasi dan promosi kesehatan ini berupa penerapan hidup sehat pada penderita TB dan keluarganya dalam ruang lingkup sehari-hari:

a) Mengupayakan posisi aliran udara ke kamar penderita TB tidak berhadapan dengan posisikeberadaan seseorang

b) Mengupayakan ruangan masuk sinar matahari 
c) Upayakan aliran udara yang masuk ruangan merupakan udara segar, berasal dari taman, ruangan terbuka yang bebas polusi

d) Pisahkan ruang tidur untuk sementara waktu

e) Gunakan masker bila ingin bersama keluarga, untuk meminimalkan kemungkinan tertularnya anggota keluarga lain

f) Bila ada anggota keluarga yang menderita batuk lebih dari 3 minggu, yang tidak sembuh dengan pengobatan biasa, segera periksakan ke dokter

g) Edukasi dan promosikan pada pasien, keluarganya dan sebagai masyarakat secara keseluruhan akan kepatuhan berobat, dan menerapkan pola hidup sehat.

\section{SIMPULAN DAN SARAN}

Berdasarkan hasil penelitian yang dilakukan, maka dapat ditarik simpulan bahwa penderita tuberkulosis paru mendapatkan dukungan yang baik dari keluarga berupa dukungan emosional, dukungan instrumental, dukungan informasi, dan dukungan penghargaan. Selain itu, keluarga juga selalu memberikan motivasi untuk sembuh pada penderita tuberkulosis paru. Dari hasil penelitian yang dilakukan menemukan pula bahwa penderita tuberkulosis paru lebih membutuhkan dukungan emosional dari keluarga yaitu berupa perhatian pada pengobatan yang dijalani oleh penderita.

Diharapkan kepada Pemerintah khususnya Dinas Kesehatan bekerja sama dengan pihak Puskesmas agar lebih meningkatkan lagi programprogram penanggulangan Tuberkulosis Paru (TB) baik itu dalam bentuk penyuluhan ataupun edukasi pada penderita tentang pentingnya dukungan dari keluarga terhadap kesembuhan penderita tuberkulosis paru melalui keteraturan dalam masa pengobatan selama 6 bulan serta memberdayakan PMO bagi penderita baik itu petugas kesehatan dan keluarga pasien.

Diharapkan kepada keluarga agar senantiasa memberikan dukungan penuh serta selalu menjaga dan memperhatikan kebersihan lingkungan rumah untuk mendukung kesembuhan penderita TB. Begitupun bagi penderita TB untuk lebih memahami keadaan tentang penyakit TB dan menghindari faktor risiko yang dapat menyebabkan terjadinya penularan serta harus lebih sabar dalam menjalani pengobatan hingga sembuh. Selain itu kepada masyarakat agar selalu memberikan dukungan semangat dalam menjalankan pengobatan pada penderita tuberkulosis paru untuk sembuh dan tidak menjauhi ataupun mendiskriminasi penderita.

\section{DAFTAR PUSTAKA}

1. Who Global Tuberculosis Report 2017. 2017. World Health Organization. Geneva.

2. Kementrian Kesehatan RI. 2012. Pedoman Nasional Program Pengendalian Penyakit Kusta. Jakarta: Kementerian Kesehatan Republik Indonesia.

3. Kementrian Kesehatan RI. 2015. Profil Kesehatan Indonesia Tahun 2014. Jakarta.

4. Dinas Kesehatan Provinsi Sultra. Profil Kesehatan Sulawesi Tenggara Tahun 20162017. Sulawesi Tenggara.

5. Dinas Kesehatan Kota Kendari. Profil Kesehatan Kota Kendari Tahun 2016-2017. Kota Kendari.

6. Who Global Tuberculosis Report 2013. 2013. World Health Organization. Geneva.

7. Departemen Kesehatan RI. 2007. Pedoman Nasional Penanggulangan Tuberkulosis. Jakarta: Departemen Kesehatan Republik Indonesia.

8. Melisa. 2012. Hubungan Dukungan Sosial Dengan Kualitas Hidup Pada Pasien Tuberkulosis Paru Di Poli Paru Blu Rsup Prof.Dr.R.D Kandou Manado. Ejournal Keperawatan (E-Kp) Volume 1 No 1.

9. Ginting, T. 2008. Faktor-Faktor Yang Mempengaruhi Terhadap Timbulnya Gangguan Jiwa Pada Penderita Tuberkulosis Paru Dewasa Di Rumah Sakit Persahabatan. Jurnal Respir Indo Vol 28 No 1

10. Hutapea, T. P. 2009. Pengaruh Dukungan Keluarga Terhadap Kepatuhan Minum Obat Anti Tuberkulosis. Jurnal Respirologi Indonesia [Serial On The Internet], 29(2).

11. Rachmawati, T., \& Turniani, L. 2006. Pengaruh Dukungan Sosial Dan Pengetahuan Tentang Penyakit Tb Terhadap Motivasi Untuk Sembuh Penderita Tuberkulosis Paru Yang Berobat Di Puskesmas. Buletin Penelitian Sistem Kesehatan, 9(3)

12. Saraswati W. Gambaran Dukungan Sosial Kelaurga Terhadap Klien Tuberkulosis Paru Yang Berobat Di Puskesmas Kecamatan Jagakarsa. Fak Keperawatan UI. 2012

13. Nuraenah. 2012. Hubungan Dukungan Keluarga Dan Beban Keluarga Dalam Merawat Angota 
Dengan Riwayat Perilaku Kekerasan Di Rs Jiwa Islam Klender Jakarta Timur. Tesis. Jakarta: Universitas Indonesia.

14. Nursalam Dan Kurniawati, N.D. 2007. Asuhan Keperawatan Pasien Terinfeksi. Hiv/Aids. Jakarta.

15. Sardiman, A. 2001.Interaksi Danmotivasibelajar Mengajar. Jakarta: Raja Grafindo.

16. Friedman, M.M., 1998 Family Nursing: Research, Theory And Practice. (4th Ed.), California: Appleton And Lange.

17. Herry. 2011. Tingkat Kecemasan, Dukungan Sosial, Dan Mekanisme Koping Terhadap Kelentingan Keluarga Pada Keluarga Dengan Tb Paru Di Kecamatan Ciomas Bogor

18. Nurhidayana, dkk. 2018. Keberhasilan Pengobatan Tuberkulosis (TB) Paru Di Wilayah Kerja Puskesmas Panambungan Kota Makassar. Program Studi Kesehatan Masyarakat Universitas Islam Negeri Alauddin Makassar, Indonesia. Volume 4, No. 1, Jan Uari-April 2018.

19. Nainggolan, H. R. N. 2013. Faktor Yang Berhubungan Dengan Gagal Konversi Pasien Tb Paru Kategori I Pada Akhir Pengobatan Fase Intensif Di Kota Medan (Thesis)

20. Amaliah, R. $2012 . \quad$ Faktof-Faktor Yangberhubungan Dengan Kegagalankonversi Penderita Tb Paru Bta Positifpengobatan Fase Intensif Di Kabupatenbekasi Tahun 2010. Fakultas Kesehatanmasyarakat Universitas Indonesia

21. Syam, M. S., Riskiyani, S., \& Rachman, W. A. Dukungan Sosial Penderita Tuberculosis Paru Di
Wilayah Kerja Puskesmas Ajangale Kabupaten Bone Tahun 2013 Social Support Of Pulmonary Tuberculosis Patients Working At Health District Ajangale Bone Year 2013.

22. Smet, B. 2009. Keperawatan Kesehatan Komunitas Teori Dan Praktik Dalam Lingkup Sosial. Jakarta:PT.Gramedia

23. Ulfah, M. 2013. Hubungan Dukungan Keluarga Terhadap Kepatuhan Minum Obat Pada Pasien Tuberkulosis (TBC) Di Wilayah Kerja Puskesmas Pamulang Kota Tangerang Selatan Tahun 2011

24. Mudatsir, dkk. 2017. Pengalaman Keluarga Dalam Memberikan Dukungan Keluarga Pada Penderita Kusta. Jurnal Ilmu Keperawatan.

25. Murni Citra Dewi, 2015. Gambaran Keberhasilan Pengobatan Pada Pasien Tuberkulosis Paru Bta (+) Di Wilayah Kecamatan Ciputat, Kota Tangerang Selatan Tahun 2015. (Skripsi). Fakultas Kedokteran Dan IImu Kesehatan Universitas Negeri Syarif Hidayatullah Jakarta.

26. Hasan Hidayah, 2018. Pengaruh Sosial Budaya Dan Sikap Petugas Terhadap Keberhasilan Kesembuhan Tb Paru Di Puskesmas Semula Jadi Kecamatan Datuk Bandar Timur Kota Tanjungbalai. Medan: Universitas Sumatera Utara.

27. Prijosaksono, A. 2001. Self Management Series. Jakarta: Gramedia.

28. Darmanto, D. 2014. Respirology. Edisi 2. Jakarta: Penerbit Buku Kedokteran. 